\title{
Review Journal of Chemistry
}

DOI: $10.1134 / \mathrm{S} 1061934811030129$

Editor-in-chief: Academician N.S. Zefirov, Russian Academy of Sciences:

Phone:+7(495)939-02-90

Fax: +7(495)939-02-90

E-mail: zefirov@org.chem.msu.ru

Executive secretary: N.V. Yashin, Department of Chemistry, Moscow State University:

Phone: +7(495)939-51-55

Fax: +7(495)939-02-90

E-mail: yashin-n@org.chem.msu.ru

You are invited to become an author of a new peerreviewed chemical review journal, founded by Pleiades Publishing Inc., and supported by the International Association of Academies of Sciences.

The journal will collect reviews by authors from the Russian Federation and CIS countries, as well as by their colleagues from other countries; it will be published in Russian- and English-language versions.

The journal's periodicity is four issues per year; it includes critical reviews on state-of-the-art problems in chemistry and neighboring interdisciplinary fields of knowledge.

The journal publishes not only reviews solicited by the editorial board, but also those written at authors' initiative. The authors of published reviews receive royalties.

The journal is published both in electronic and printed versions. The Russian-language version of Review Journal of Chemistry will be distributed via www.eLibrary.ru, which is now the major online supplier of scientific information in the former Soviet Union. The English-language version is accessible worldwide via Springerlink.com within the limits of the program Russian Library of Science. Therefore, an author's work will not only be published side-by-side with reviews by leading experts from Russia and CIS countries in this new journal, but will also be covered by global search, which will include leading publications of researchers worldwide, and be indexed in all prestigious databases.

\section{V.A. Davankov awarded Zwett and Nernst Prize}

DOI: $10.1134 / \mathrm{S} 1061934811030129$

The European Society for Separation Science has awarded the Zwett and Nernst Prize to Doctor of Chemistry, Professor Vadim Aleksandrovich Davankov (Nesmeyanov Institute of Organoelement Compounds of the Russian Academy of Sciences). The decision approved by the Society Committee on June 5, 2010, emphasizes Davankov's great contribution by solving problems of separation and life sciences.

\section{From the Editor-in-Chief}

DOI: $10.1134 / \mathrm{S} 1061934811030129$

It was found that the paper by M.S. Gidwani, H. Kaur, Usha Pal, and S.K. Menon "A Chromogenic Calixarene Hydroxamic Acid for the Sequential Separation of $\operatorname{Ti}(\mathrm{IV})$ and $\operatorname{Zr}(\mathrm{IV})$ " (Zh. Analit. Khim., 2009, vol. 64, no. 2, pp. 118-123 [J. Analyt. Chem., 2009, vol. 64, no. 2, pp. 104-109]) contained materials published earlier without corresponding references to them. Some results presented in the paper raised questions about their origin, which were not answered by the authors. In this connection, the paper has been excluded from the journal and its citation is forbidden. 